Marta Czerska

Karolina Mikołajewska

Marek Zielinski

Jolanta Gromadzińska

Wojciech Wasowicz

\title{
TODAY'S OXIDATIVE STRESS MARKERS
}

\author{
WSPÓŁCZESNE MARKERY STRESU OKSYDACYJNEGO
}

Nofer Institute of Occupational Medicine / Instytut Medycyny Pracy im. prof. J. Nofera, Łódź, Poland

Department of Toxicology and Carcinogenesis / Zakład Toksykologii i Kancerogenezy

\begin{abstract}
Oxidative stress represents a situation where there is an imbalance between the reactive oxygen species (ROS) and the availability and the activity of antioxidants. This balance is disturbed by increased generation of free radicals or decreased antioxidant activity. It is very important to develop methods and find appropriate biomarkers that may be used to assess oxidative stress in vivo. It is significant because appropriate measurement of such stress is necessary in identifying its role in lifestyle-related diseases. Previously used markers of oxidative stress, such as thiobarbituric acid reactive substances (TBARS) or malondialdehyde (MDA), are progressively being supplemented by new ones, such as isoprostanes (IsoPs) and their metabolites or allantoin. This paper is focusing on the presentation of new ones, promising markers of oxidative stress (IsoPs, their metabolites and allantoin), taking into account the advantage of those markers over markers used previously. Med Pr 2015;66(3):393-405
\end{abstract}

Key words: isoprostanes, oxidative stress, oxidative stress markers, allantoin, metabolites of isoprostanes

\section{STRESZCZENIE}

Stres oksydacyjny jest stanem braku równowagi między działaniem reaktywnych form tlenu (RFT) a działaniem antyoksydantów. Równowaga ta może być zakłócona w wyniku zwiększonego działania wolnych rodników lub spadku aktywności antyoksydacyjnej. Zaburzenia te mogą występować zarówno na poziomie komórkowym, jak i całego organizmu. Ponieważ stres oksydacyjny może być podłożem wielu zespołów chorobowych, niezwykle istotne jest znalezienie odpowiednich markerów, które mogą być wykorzystane do oceny jego poziomu in vivo. Stosowane od wielu lat markery - ocenę stężenia aldehyd dimalonowy (MDA) i substancji reagujących z kwasem tiobarbiturowym (thiobarbituric acid reactive substances - TBARS) - stopniowo uzupełnia się nowymi, takimi jak alantoina czy izoprostany (IzoP) wraz z ich metabolitami (IzoP-M). W niniejszej pracy skupiono się na zaprezentowaniu nowych, obiecujących markerów stresu oksydacyjnego (alantoina, IzoP, IzoP-M), ukazując korzyści wynikające z ich stosowania i prognozując dalsze kierunki badań nad ich zastosowaniem. Med. Pr. 2015;66(3):393-405

Słowa kluczowe: izoprostany, stres oksydacyjny, markery stresu oksydacyjnego, alantoina, metabolity izoprostanów

Corresponding author / Autorka do korespondencji: Marta Czerska, Nofer Institute of Occupational Medicine,

Department of Toxicology and Carcinogenesis, św. Teresy 8, 91-348 Łódź, Poland, e-mail: m-czerska@wp.pl

Received: October 16, 2014, accepted: February 27, 2015

\section{INTRODUCTION}

Oxidative stress is defined as the presence of active oxygen species in excess of the available antioxidant buffering capacity. These products, reactive oxygen species, may damage proteins, lipids, DNA, proteins and carbohydrates changing the organism's structure and functions. Tissue damage is due to a number of enzyme and non-enzyme-mediated biochemical reactions which produce extremely reactive intermediate compounds free radicals. These free radicals are either endogenous and/or exogenous [1,2]. Major reactive oxygen species as divided into free radicals and reactive oxygen species are listed in the Table 1 [3].

The body has an effective buffering system of these products but it will not be able to produce it some-

Funding / Finansowanie: this study was performed under the projects: IMP.1.32. “The concentration of F2 isoprostane in biological samples of the Lodz healthy population" and IMP 1.25. "Development of methods for the determination of isoprostane F2-IsoP in biological materials by GC-MS.” Project manager: Marek Zieliński, M.A. 
Table 1. Major active oxygen species

Tabela 1. Główne aktywne formy tlenu

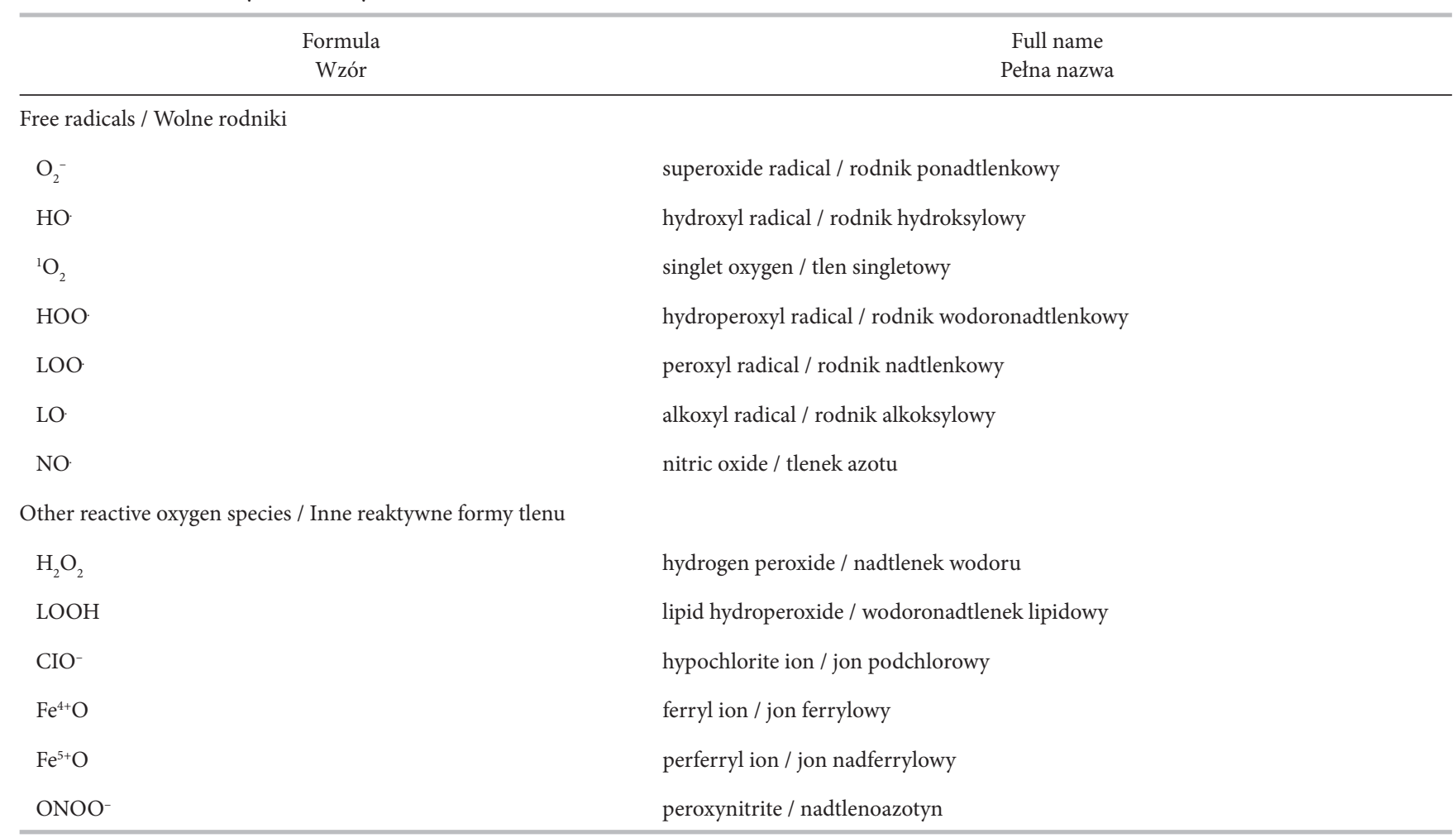

times. Oxidative stress is well known to be involved in the pathogenesis of lifestyle-related diseases, including hypertension, diabetes mellitus, ischemic diseases, malignancies, or Alzheimer disease, Parkinson's disease, and amyotrophic lateral sclerosis [3-5]. Oxidative damage has been identified even in early stages of these diseases, indicating that their aetiologies are linked to free radicals. Oxidative compounds are also physiologically relevant in inflammation and tissue repair processes. Hence, they represent some defence mechanisms against microorganisms and malignant cells as well as tissue healing and remodelling [6].

On the other hand, improper or maladaptive activation of oxidative processes may be chronically present in various pathological situations [6]. Oxidative stress is known to be harmful because of oxygen free radicals that attack biological molecules, like lipids or proteins, and also DNA. Still, oxidative stress has also a useful role in physiologic adaptation and in the regulation of intracellular signal transduction [3]. Therefore, a more useful definition of oxidative stress may be "a state where oxidative forces exceed the antioxidant systems due to loss of the balance between them" [3]. In other words, oxidative stress may be defined as the tissue damage resulting from an imbalance between excessive generation of oxidant compounds and insufficient anti-oxidant defence mechanisms [7].

The biomarkers that may be used to assess oxidative stress in vivo have been attracting interest in recent years because the accurate measurement of such stress is necessary to investigate their role in lifestyle diseases or also to evaluate the success of treatment. Free radicals have very short half-life (of the order of few seconds) and their measurement in vivo is faced with many challenges. However, oxy radical derivatives (e.g., hydrogen peroxide or lipid hydroperoxides) are stable and have long half-life (hours to weeks) and thus may be measured and monitored repeatedly.

Many oxidative markers found in the body have been proposed, including lipid hydroperoxides, 4-hydroxynonenal, isoprostanes (IsoPs), 8-hydroxy-2-deoxyguanosine (8-OHdG), malondialdehyde (MDA), allantoin or thiobarbituric acid reactive substances (TBARS). To prevent the development of lifestyle related diseases, advice on how to lead a healthy life should be given, including particulars based on the levels of oxidant and antioxidant activity assessed by appropriate biomarkers. Individual genetic information should also be taken into consideration when giving such instructions [3]. Lately, some of them have aroused an interest 
Table 2. Markers of oxidative stress

Tabela 2. Markery stresu oksydacyjnego

\begin{tabular}{|c|c|}
\hline $\begin{array}{l}\text { Processes } \\
\text { Proces }\end{array}$ & $\begin{array}{l}\text { Markers of oxidative stress } \\
\text { Markery stresu oksydacyjnego }\end{array}$ \\
\hline Lipid peroxidation / Peroksydacja lipidów & $\begin{array}{l}\text { malondialdehyde (MDA) / dialdehyd malonowy } \\
\text { F2-isoprostanes / F2-izoprostany } \\
\text { oxidized low-density lipoproteins (LDL) / utlenione lipoproteiny o niskiej gęstości } \\
\text { oxidized LDL antibodies / przeciwciała utlenionych LDL } \\
\text { advanced lipid oxidation products / produkty zaawansowanego utleniania lipidów } \\
\text { acrolein / akroleina } \\
\text { 4-hydroxynonenal / 4-hydroksynonenal }\end{array}$ \\
\hline Protein oxidation / Utlenianie białek & $\begin{array}{l}\text { thiobarbituric acid reactive substances (TBARS) / substancje reagujące z kwasem } \\
\text { tiobarbiturowym } \\
\text { advanced oxidation protein products / produkty zaawansowanego utleniania białek } \\
\text { advanced glycation end-products (AGEs) / końcowe produkty zaawansowanej glikacji } \\
\text { disulfite formation / utlenianie grup tiolowych }\end{array}$ \\
\hline Nucleic acid oxidation / Utlenianie kwasów nukleinowych & $\begin{array}{l}\text { reactive aldehydes / aeaktywne aldehydy } \\
\text { reduced sugar (ascorbate, ribose, etc.) / zredukowane cukry (askorbinian, ryboza itd.) } \\
\text { 8-oxy-2-deoxyguanosine / 8-oksy-2-deoxyguanozyna }\end{array}$ \\
\hline
\end{tabular}

throughout science world. These are markers such as IsoPs, isoprostane metabolites, allantoin or 8-oxydG. Markers of oxidative stress are summarized in the Table 2 [8].

Over the years, MDA and TBARS were the most often analysed markers of oxidative stress. Recently, these markers are supplemented by far more accurate ones. These include isoprostanes, their metabolites and allantoin. Since isoprostanes were discovered, there have appeared a lot of evidence that they are reliable markers of oxidative damage in vivo and in vitro, relatively susceptible to quantitative determination in biological fluids.

Allantoin is the end product of non-enzymatic oxidation of uric acid. Allantoin is a promising biomarker of systemic oxidative status in humans because concentration of allantoin does not depend on variations of uric acid level [9]. Moreover, allantoin is stable regardless of the storage or sample preparation, and additionally it is easily detected in biological material of human samples.

\section{ALLANTOIN}

The search for reliable markers of oxidative stress, which are assayed in the urine may contribute to progress in the wide-scale epidemiological and clinical studies of oxidative stress. There are several reports concerning the determination of allantoin in human urine [10-14]. Allantoin (5-ureidohydantoine) has recently been considered a promising biomarker of prooxidative processes $[12,13]$ specific only for apes and humans [15].

In the human body, allantoin is formed in the reaction of non-enzymatic oxidation of uric acid by reactive oxygen and nitrogen species (ROS/RNS) $[13,16]$. Uric acid is the end product of purine metabolism in humans [9]. Under physiological conditions, uric acid is a powerful antioxidant and scavenger of ROS/RNS found in the cytosol of the cell and in the extracellular spaces [17]. Overproduction of ROS/RNS degrades uric acid to allantoin [9].

Levels of allantoin in plasma or serum was reported in several studies as a marker for the activity of free radicals $[16,18,19]$. Allantoin production is independent of changes in the concentration of uric acid, and therefore, may be a good biomarker for assessing oxidative status in humans. It has been shown that the concentration of allantoin in the plasma increases in heavy smokers [20], type 2 diabetics [9,21], patients after chemotherapy [22], neonatal hypoxia during labour [23]. It was also found that the concentration of allantoin correlated with other markers of oxidative stress analyzed in the urine (e.g., F2-isoprostanes).

Grootveld and Halliwell [16] showed higher concentrations of allantoin in serum of patients with 
rheumatoid arthritis (RA) than in the control group $(36.1 \pm 3.6 \mu \mathrm{mol} / \mathrm{l}$ vs. $18.6 \pm 3.8 \mu \mathrm{mol} / \mathrm{l})$. However, the study group was small [16]. Yardim et al. [24] performed a study, in which they analysed the participation of ROS in rheumatoid arthritis. Concentration of allantoin was used as a marker for oxidation of uric acid. The levels of allantoin determined by the authors of the study ranged $17.0-27.2 \mu \mathrm{mol} / \mathrm{l}$ in patients and $10.1-17.0 \mu \mathrm{mol} / \mathrm{l}$ in healthy adults [24]. Much lower concentrations of allantoin in plasma were found by Turner et al. [25]. In patients with RA, the levels of allantoin ranged 3.0-5.6 $\mu \mathrm{mol} / \mathrm{l}$ whereas in healthy adults the respective values were $1.4-3.6 \mu \mathrm{mol} / \mathrm{l}$ [25]. This could be caused by performing the analysis using a more sensitive and specific analytical method (hydrophilic interaction liquid chromatography with tandem mass spectrometry - HILIC-MS/MS) which excludes formation of artefacts, and thus the overestimation of results is less likely.

It is also known that free radicals participate in the pathogenesis of some of the complications related with long dialysis therapy. Kand'ár et al. [9] observed a significant increase in the level of allantoin in plasma up to $27.12 \pm 13.78 \mu \mathrm{mol} / \mathrm{l}$ in patients with chronic renal failure whereas in healthy subjects that level was $4.67 \pm 2.99 \mu \mathrm{mol} / 1(\mathrm{p}<0.001)$ [9].

Chung and Benzie [21] showed that type 2 diabetes patients had higher concentrations of plasma allantoin than healthy controls $(8.82 \pm 7.26 \mu \mathrm{mol} / \mathrm{l}$ vs. $1.08 \pm 0.86 \mu \mathrm{mol} / \mathrm{l} ; \mathrm{p}<0.0001)$. Higher level of allantoin was reported in diabetic men $(11.57 \pm 8.57 \mu \mathrm{mol} / \mathrm{l}$; $\mathrm{N}=14)$ than women $(6.99 \pm 5.75 \mu \mathrm{mol} / \mathrm{l} ; \mathrm{p}<0.05$; $\mathrm{N}=21$ ) [21]. Similarly, Kand'ár et al. [9] reported that in patients with type 2 diabetes (non-insulin dependent diabetes mellitus - NIDDM), the level of allantoin was higher than in healthy adults (concentrations of allantoin are shown in the Table 3) [9].

Vigorous physical exercise also affects the concentration of allantoin. Hellsten et al. [26] reported an increased level of allantoin in the muscles during vigorous exercise. It is caused by generation of radical molecules. Studies were performed in a small healthy group of men $(\mathrm{N}=7)$ and involved short vigorous exercise on a bike. Biopsies of vastus lateralis muscle were made during the exercise. Samples were obtained in the non-occluded leg muscle (0.7 min, $1.1 \mathrm{~min}, 2.9 \mathrm{~min}$ after the end of exercise) and in the occluded leg (immediately after exercise and at $3.6 \mathrm{~min}$ afterwards). The concentration of allantoin in the muscle tissue was $0.03 \pm 0.007 \mu \mathrm{mol} / \mathrm{g}$ during resting time, and increased

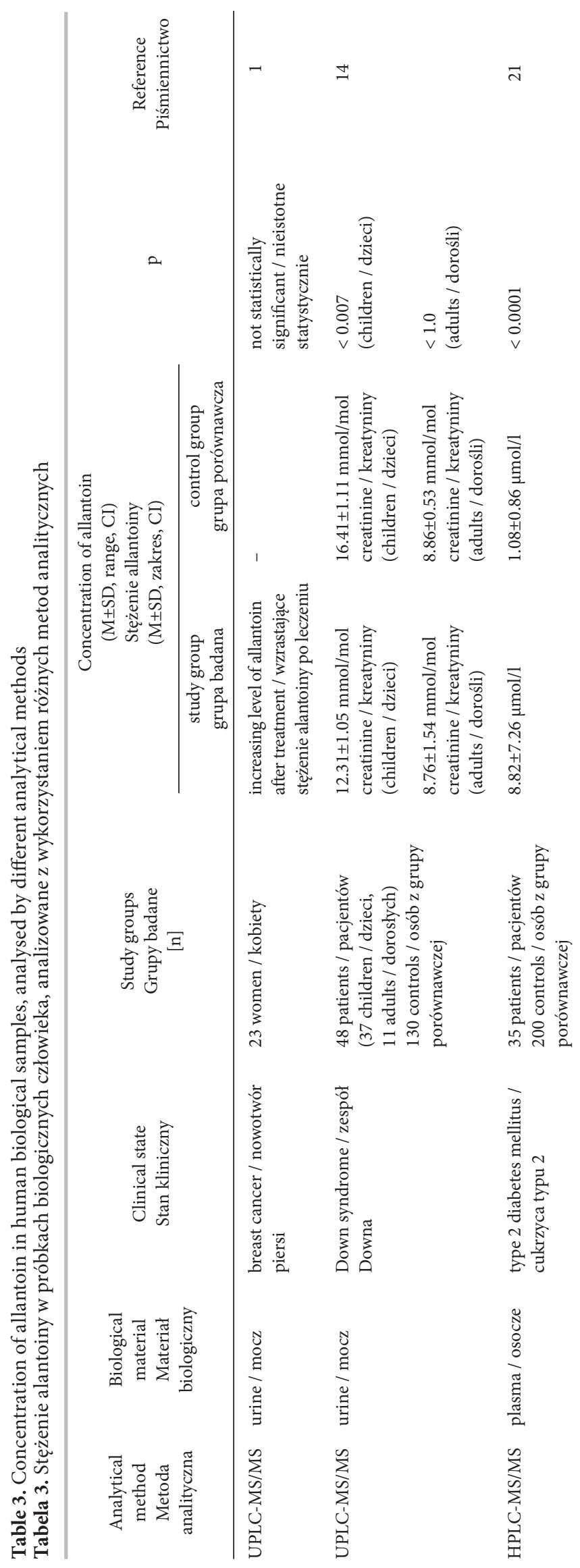




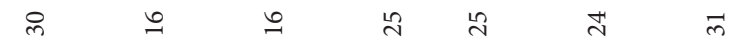

ลิ

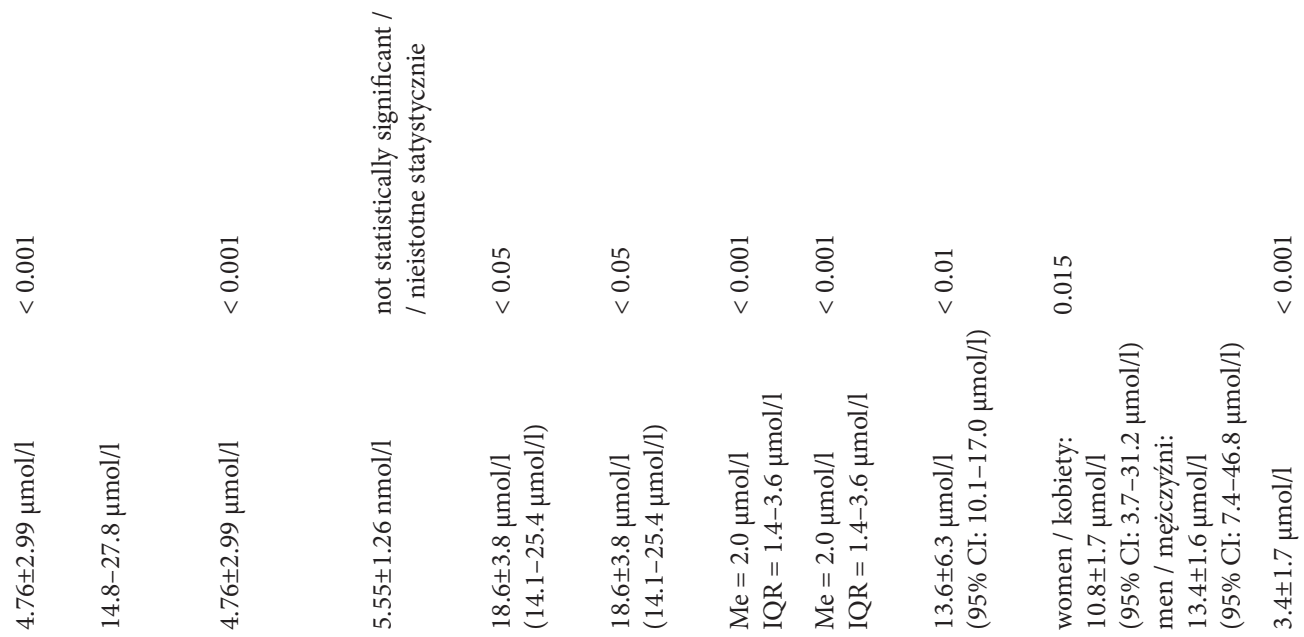

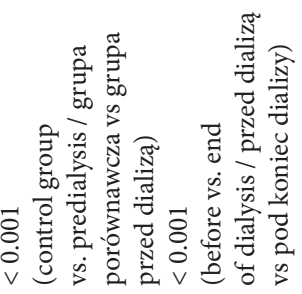

울

50

营

至

吾

चु के हू

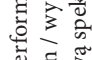

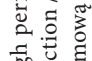

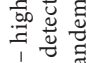

$\sum \stackrel{\infty}{\infty}$

$\sum_{1}^{\infty} \sum_{0}^{\infty}$

诂考要

o है

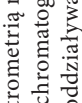

离.

幽

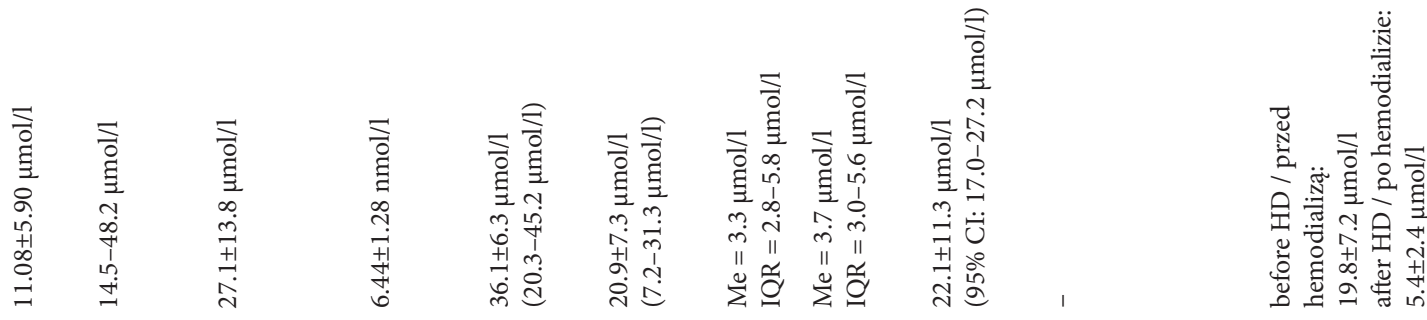

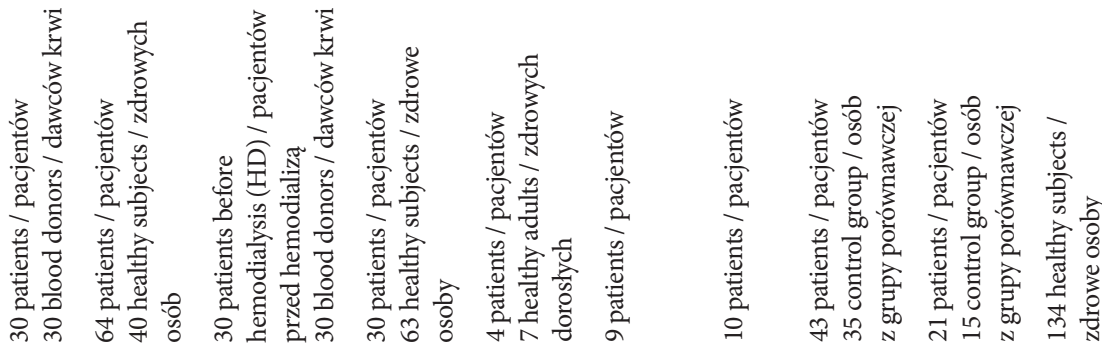

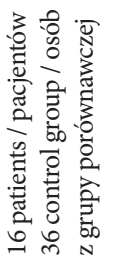

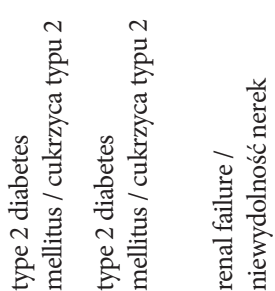

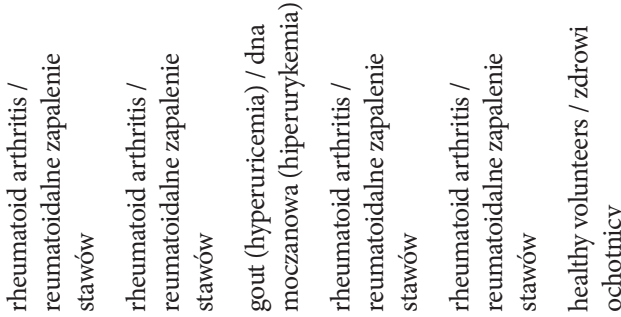

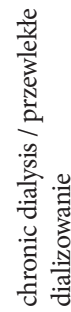

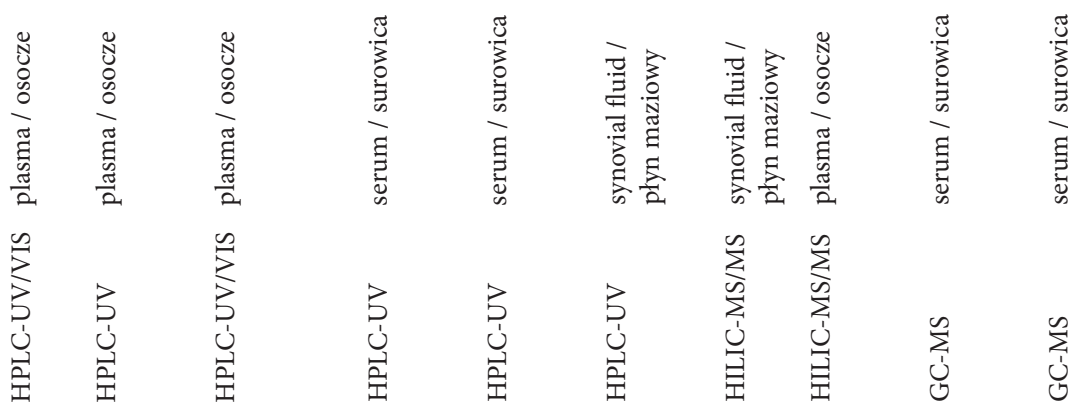


immediately after the exercise to $0.10 \pm 0.014 \mu \mathrm{mol} / \mathrm{g}$. After 3 min of exercise, concentration of allantoin decreased to stand at $0.079 \pm 0.002 \mu \mathrm{mol} / \mathrm{g}(\mathrm{p}<0.05)$. Concentration of allantoin in plasma at rest was $11.9 \pm 2.6 \mu \mathrm{mol} / \mathrm{l}$ whereas after the exercise it was 2 times higher within $5 \mathrm{~min}$, and remained high throughout recovery $(\mathrm{p}<0.05)[26]$.

In another report, Gus'kov et al. [23] describe statistically significant decrease in concentration of allantoin in placenta, in the first trimester of pregnancy, which was observed in women with non-progressive pregnancy $(4.21 \pm 0.14 \mu \mathrm{mol} / \mathrm{g}$ protein; $\mathrm{p}<0.001 ; \mathrm{N}=10)$, compared with women with physiological pregnancy $(5.18 \pm 0.13 \mu \mathrm{mol} / \mathrm{g}$ protein; $\mathrm{N}=35)$. On the other hand, early miscarriages were associated with increased concentration of allantoin in placenta $(6.54 \pm 0.42 \mu \mathrm{mol} / \mathrm{g}$ protein; $\mathrm{p}<0.05 ; \mathrm{N}=10$ ). Allantoin was analysed in homogenates of chorion and placental villi. Similarly, in the 2nd trimester of pregnancy, Gus'kov et al. [23] observed higher concentration of allantoin in normal pregnancy $(5.01 \pm 0.34 \mu \mathrm{mol} / \mathrm{g}$ protein) than in women with late miscarriages $(2.03 \pm 0.32 \mu \mathrm{mol} / \mathrm{g}$ protein; $\mathrm{p}<0.001 ; \mathrm{N}=10$ ). It was probably associated with the development of hypoxia in the placenta. Moreover, it contributed to the activation of free radicals generation and non-enzymatic degradation of uric acid resulting in formation of allantoin [23].

Cigarette smoking may contribute to the development of diseases involving oxidative damage. It also affects the plasma concentration of allantoin. However, Seet et al. [20] observed that allantoin concentration increased after cigarette smoking, while during the night abstinence there was no difference in the concentrations of allantoin [20].

Allantoin may also be useful to evaluate the efficiency of cancer treatment. Il'yasova et al. [22] performed a study in women with breast cancer. The authors found that the assessment of the allantoin concentration during treatment chemotherapy may help to identify cancer patients, who are particularly resistant to drug treatment [22].

Despite the fact that allantoin is considered as a specific biomarker of oxidative stress, it is not commonly used as a biomarker [9,19,21]. Allantoin is an extremely polar compound, therefore quantitative determination in plasma, serum or urine is difficult [10]. It requires the use of sensitive and specific analytical techniques [21]. Allantoin was determined by means of capillary zone electrophoresis (CZE) [27], enzymatic assay and enzyme cycling method [28], capillary electrophoresis with UV detection (CE-UV) [29], high performance liquid chromatography - UV detection (HPLC-UV) [9,30], ultra performance liquid chromatography - tandem mass spectrometry (HPLC/UPLC-MS/MS) [10-14,21], and gas chromatography - mass spectrometry (GC-MS) [20,24,31], and allantoin is detected readily in urine, plasma, and synovial fluid [25].

Moreover, repeated freezing and thawing of the urine samples do not affect the concentration of allantoin, just like the preparation of the sample and storing it at room temperature for up to 6 days. In the fridge, it remains stable for 12 days, while in the deep frozen $\left(-70^{\circ} \mathrm{C}\right)$ urine sample, it is stable at least for 15 weeks [10,12]. Gas chromatography - mass spectrometry is more sensitive than the HPLC method. However, it requires more time-consuming sample preparation, mainly due to the derivatisation step. In addition, each step increases the probability of an additional loss of analyte. The molar factor of the absorbance of allantoin is high enough to enable to assay allantoin by UV detection. However, plasma is a complicated matrix, consisting of a plurality of compounds resulting in a signal in the wavelength range of $220 \mathrm{~nm}$. On the other hand, allantoin may be unambiguously identified by GC-MS [31].

For many years, quantitative determination of allantoin in the biological material was difficult due to insufficiently sensitive / specific instrumental techniques. The results were often overestimated [32]. This could be caused by insufficient purification of samples prior to the analysis, especially complicated, complex matrix. In addition, the polar character of the compound impeded the determination. Allantoin concentrations are estimated at the level of a few/several micromoles per litre. However, older studies showed much higher concentrations of allantoin $[16,24]$ than those performed by the more recent instrumental techniques [21,25]. Current methods, both liquid and gas chromatography with mass spectrometry are more sensitive and more specific. Often they do not require complicated multistep purification of biological samples $[21,33]$.

The Table 3 presents data on the determination of the concentration of allantoin in human biological material analyzed using a variety of analytical methods. Based on this data it may be concluded that the analysis of allantoin by means of different methods may have a significant impact on the final result. Furthermore, the data in the above table is reported in the range of more than 20 years. This is important, because the equipment for instrumental analysis has significantly improved in terms of quality. Comparing, 
for example, allantoin concentrations in healthy persons determined in the serum by means of the HPLC-UV method, as reported by Grootveld and Halliwell (1987) [16], was much higher than indicated by means of the same chromatographic technique by Kurajoh et al. [30] in the report from 2012.

Slightly higher concentrations in the control group were observed by determining allantoin by means of gas chromatography than in the case of liquid chromatography, regardless of the detection method, excluding, however, the liquid chromatography method under older studies reported before 2002 .

Although GC-MS is a more sensitive method than HPLC, however, as mentioned previously, each sample preparation step increases the probability of an additional loss of analyte or contaminants, which can lead to an overestimation of the results.

From the above observations it appears that the most sensitive and specific method for determining allantoin is liquid chromatography, both high performance liquid chromatography and hydrophilic interaction liquid chromatography.

Urine seems to be the best biological material, mainly due to the non-invasive, easy sampling. There are, however, not many reports on the determination of allantoin in the urine.

Whereas the concentration of allantoin, analysed in serum, within the same diseases provides a higher concentration than in the synovial fluid, both taking into account, the same analytical method [16] and different methods (HPLC-UV vs. HILIC-MS/MS reports from 2012) $[25,30]$. It is not clear in the case of the analysis of allantoin in serum and plasma because as far as the data in the Table 3 is concerned, it may be seen that concentration of allantoin in serum, in patients before dialysis, was lower than in plasma. However, they were analyzed by means of different analytical methods, GC [29] and HPLC-UV/VIS [9]. Furthermore, the data comes from reports from 1999 and 2010, which makes comparisons difficult. In patients with RA, concentrations of allantoin were higher in serum than in plasma. However, studies were conducted using various chromatographic techniques such as GC [24] and HPLC [25].

The differences between the concentrations of allantoin in the group of healthy individuals and patients depend on the type of disease.

Examining levels of allantoin in diseases of the kidney is indicative of an increase in the concentration of allantoin before treatment as compared to allantoin concentrations in healthy subjects and significant reduction in its concentration after treatment (Table 3).

Slight but significant differences may be observed in patients with gout. However, these concentrations are lower than in the case of patients before dialysis.

It is difficult to compare data from patients with rheumatoid arthritis because there are few reports in the literature. In addition, some of the data date back to 1987 , and moreover, it was analysed in a different biological material and by means of a different analytical method.

However, if taking into account the most recent literature data from 2012, it may be observed that the concentrations of allantoin in patients with rheumatoid arthritis (RA) as compared to the concentrations in patients with other diseases are much lower. Despite this, in relation to a group of healthy subjects, they are statistically significant within disease. In the case of type 2 diabetes mellitus there are statistically significant differences as compared to healthy individuals. Similarly, in comparison to other diseases, observed concentrations are higher. It follows that allantoin is a good biomarker for the diagnosis of renal diseases, rheumatoid arthritis, and type 2 diabetes mellitus.

However, there is little data which would clearly determine, in which biological material, and which analytical method of analysing allantoin concentration may provide the most reliable results, especially in the case of different diseases.

\section{ISOPROSTANES}

Isoprostanes are prostaglandin (PG) isomers that are generated from polyunsaturated fatty acids, mainly from arachidonic acid by a non-enzymatic process that involves peroxidation of membrane phospholipids by free radicals and reactive oxygen species [34]. The first discovered class of isoprostanes included the $\mathrm{F}_{2}$-IsoPs, named according to the type of cyclopentane ring [35]. Now, 3 types of nomenclature are used: former nomenclature, Taber's nomenclature and Rokach's nomenclature [36].

There are some differences between prostaglandins (PGs) and isoprostanes. The main difference is the way of formation: PGs are formed by the action of cyclooxygenases (COX-1 and COX-2), isoprostanes are formed non-enzymatically as a result of free radical-mediated mechanism [37]. Prostaglandin side chains are trans and isoprostane side chains are mainly cis isomers [35]. While PGs are formed from free 
arachidonic acid, isoprostanes are formed in situ in lipid membranes from polyunsaturated fatty acids and then they are released by phospholipases. It also has been reported that isoprostanes may be formed not only from arachidonic but also from docosahexaenoic and eicosapentaenoic acids [38,39].

Strong evidence that isoprostanes are suitable oxidative stress markers includes inter alia: they are stable compounds, they are specific products of ROS induced lipid peroxidation, they have been found in detectable quantities as a free form in all biological fluids and as esterified form in normal tissues and they are unaffected by lipid content in diet [40]. That is why, since 1995, the number of studies, in which the authors have attempted to determine their levels in biological samples in clinical syndromes probably associated with oxidative stress has continued to increase [41].

Isoprostanes are present in urine, plasma, cerebrospinal fluid and exhaled breath condensate (EBC). Their levels are generally determined in urine because its collection is non-invasive and they are very stable in urine [36].

It is known that cigarette smoking, obesity, diabetes and hypercholesterolemia may lead to heart diseases. In humans with a number of these risk factors, levels of isoprostanes have been found to be higher than in potentially healthy humans [42-45].

Obata et al. [46] examined the relationship between smoking and urinary isoprostane levels $(\mathrm{N}=141)$. Those authors found that isoprostane levels were significantly different between smokers and non-smokers $(605.2 \pm 59.01 \mathrm{ng} / \mathrm{mg}$ creatinine vs. $424.0 \pm 70.37 \mathrm{ng} / \mathrm{mg}$ creatinine, $\mathrm{p}<0.05)$. They have also observed that isoprostane content in ex-smokers $(487.2 \pm 98.48 \mathrm{ng} / \mathrm{mg}$ creatinine) did not differ significantly from that one in non-smokers or smokers. In that research, correlations between isoprostane levels in urine and time after quitting smoking were found.

Also Morrow et al. [42] investigated the relationship between plasma isoprostanes (free and esterified to plasma lipids) and smoking status. They have found significant differences $(p=0.02)$ between the levels of free $\mathrm{F}_{2}$-isoprostanes in plasma from smokers $(242 \pm 147 \mathrm{pmol} / \mathrm{l})$ and non-smokers $(103 \pm 19 \mathrm{pmol} / \mathrm{l})$. Also isoprostanes esterified to lipids in plasma from smokers $(574 \pm 217 \mathrm{pmol} / \mathrm{l})$ were significantly higher $(\mathrm{p}=0.03)$ than in the case of non-smokers $(345 \pm 65 \mathrm{pmol} / \mathrm{l})$. In that study, also the influence of abstinence from smoking on $\mathrm{F}_{2}$-isoprostanes was examined. It was found that levels of both, free $(156 \pm 67 \mathrm{pmol} / \mathrm{l})$ and esterified
$(469 \pm 108 \mathrm{pmol} / \mathrm{l})$ plasma isoprostanes in subjects after 2 weeks of abstinence from smoking were significantly lower than the levels measured during smoking (free isoprostanes $250 \pm 156 \mathrm{pmol} / \mathrm{l}$, esterified isoprostanes $624 \pm 214 \mathrm{pmol} / \mathrm{l})$.

Keaney et al. [44] and Davi et al. [47] investigated the influence of obesity on urinary isoprostane levels $(\mathrm{N}=2828$ and $\mathrm{N}=20$, respectively). Both authors found a strong association between body mass index (BMI) and urinary isoprostane levels. Moreover, Davi et al. [47] observed that, with a reduction in weight, urinary isoprostane levels were also lower. It is now generally recognised that obesity may lead to diabetes. Diabetes may of course also be caused by other factors, such as genetic aspects and general lifestyle. Regardless of the origin of diabetes, higher levels of urinary and plasma isoprostanes were observed also in diabetic patients $[43,48,49]$.

Davi et al. [48] investigated association between diabetes mellitus (DM) and in vivo formation of $\mathrm{F}_{2}$ isoprostane (8-iso-prostaglandin $\mathrm{F}_{2 \mathrm{a}}$ ). They found out that urinary 8 -iso-PGF ${ }_{2 a}$ excretion was significantly higher in type 2 diabetes mellitus patients as compared to healthy subjects $(419 \pm 208 \mathrm{pg} / \mathrm{mg}$ creatinine, $\mathrm{N}=62$, vs. $208 \pm 92 \mathrm{pg} / \mathrm{mg}$ creatinine, $\mathrm{N}=85, \mathrm{p}<0.0001$ ) and it was also higher in type 1 diabetic patients than in their control subjects $(400 \pm 146 \mathrm{pg} / \mathrm{mg}$ creatinine, $\mathrm{N}=23$, vs. $197 \pm 69 \mathrm{pg} / \mathrm{mg}$ creatinine).

In the subsequent article Davi et al. [49] report that in newly diagnosed type 1 diabetic patients, levels of urinary 8-iso-PGF ${ }_{2 a}$ were significantly higher than in patients with longer-standing disease. In turn Gopaul et al. [43] studied plasma levels of 8-epi-PGF ${ }_{2 \alpha}$ in patients with type 2 diabetes. They found out that in diabetic patients, plasma levels of esterified 8 -epi-PGF ${ }_{2 a}$ were significantly higher (range: $0.49-2.16 \mathrm{nM}$ ) than in control subjects (range: $0.02-0.63 \mathrm{nM}$ ).

In patients with homozygous familial hypercholesterolemia $(\mathrm{HFH}) \quad(\mathrm{N}=38)$ [45] urinary levels of iPF $_{2 \alpha}$-III $(85 \pm 5.5 \mathrm{pmol} / \mathrm{mmol}$ creatinine, $\mathrm{p}=0.0005)$ and $\mathrm{iPF}_{2 a}-\mathrm{VI} \quad(281 \pm 22 \mathrm{pmol} / \mathrm{mmol}$ creatinine, $\mathrm{p}=0.0001)$ were higher than in control patients $(\mathrm{N}=38)$ $(58 \pm 4.2 \mathrm{pmol} / \mathrm{mmol}$ creatinine and $175 \pm 13 \mathrm{~mol} / \mathrm{mmol}$ creatinine, respectively).

Those teams of authors did not find a relationship between the levels of measured isoprostanes and gender or age.

These studies show that smoking, obesity, diabetes and hypercholesterolemia causes oxidative damage in human body. 
It has been postulated that oxidative stress plays an important role in neurodegenerative diseases. The number of studies proving an impact of free radicals on brain lipids, carbohydrates, proteins and DNA is still increasing. A large number of studies confirm the hypothesis that oxidative stress plays an important role in pathogenesis of neuron degeneration in Alzheimer Disease (AD) [50]. A number of studies have also shown that oxidative stress affects many of the clinical features of Down Syndrome (DS) [51].

Praticò et al. [52] found that in patients with probable $(\mathrm{N}=25)$ or possible $(\mathrm{N}=10) \mathrm{AD}$, levels of urinary 8,12 -iso-iPF $2 a-V I$ were significantly higher than in controls $(\mathrm{N}=25)(4.93 \pm 0.45 \mathrm{ng} / \mathrm{mg}$ creatinine, $4.18 \pm 0.56 \mathrm{ng} / \mathrm{mg}$ creatinine vs. $1.77 \pm 0.17 \mathrm{ng} / \mathrm{mg}$ creatinine, $\mathrm{p}<0.0001, \mathrm{p}<0.0001$, respectively). A similar conclusion was true about plasma iso-iPF ${ }_{2 a}-\mathrm{VI}$ $(0.68 \pm 0.05,0.67 \pm 0.08$ and $0.18 \pm 0.01 \mathrm{ng} / \mathrm{ml}$, respectively; $\mathrm{p}<0.0001)$. In samples of cerebro-spinal fluid collected from patients with probable and possible $\mathrm{AD}$, levels of 8,12-iso-iPF ${ }_{2 \alpha}$-VI were also significantly higher than in the control group [52].

Praticò et al. [51] also investigated levels of 8,12-iso$\mathrm{iPF}_{2 a}-\mathrm{VI}$ in the urine of young patients with DS $(\mathrm{N}=33)$ and compared the results with the levels in the urine of the control group $(\mathrm{N}=33)$. They found that patients with DS had significantly higher levels of this isoprostane in urine (median (Me): 1.97, range: $0.75-4.25 \mathrm{ng} / \mathrm{mg}$ creatinine, $\mathrm{p}<0.01$ ) than controls (Me: 1.20, range: $0.25-2.5 \mathrm{ng} / \mathrm{mg}$ creatinine).

The concentration of oxidative stress biomarkers in plasma or urine may reflect systemic inflammation. That is why nowadays there is an increasing interest in measuring oxidative stress markers in exhaled breath condensate (EBC) collected from patients with pulmonary disease and numerous studies are proving that it may be the best method $[53,54]$. Balardi et al. [55] measured levels of 8-isoprostane in EBC in samples collected from children with steroid-naïve asthma $(\mathrm{N}=12)$ and steroid-treated asthma $(\mathrm{N}=30)$. They have found no differences in exhaled 8-isoprostane levels between the 2 groups of asthmatic children. In samples from steroid-naïve children, the level of isoprostane was $56 \pm 7.7 \mathrm{pg} / \mathrm{ml}$, and in samples from steroid-treated children, it was $47.2 \pm 2.3 \mathrm{pg} / \mathrm{ml}$. These results were higher as compared to the samples collected from the control group $(34.2 \pm 4.5 \mathrm{pg} / \mathrm{ml})$.

Zanconato et al. investigated levels of 8 -isoprostane in EBC from steroid-naive children with mild persistent asthma $(\mathrm{N}=14)$, ICS-treated (inhaled corticostero- ids treated) children with stable mild-to-moderate persistent asthma $(\mathrm{N}=13)$ and children with unstable asth$\mathrm{ma}(\mathrm{N}=9)$ [56]. Concentrations of 8 -isoprostane in EBC were increased in all of asthmatic children groups (median: $16.2 \mathrm{pg} / \mathrm{ml} ; 18.1 \mathrm{pg} / \mathrm{ml} ; 29.7 \mathrm{pg} / \mathrm{ml}$, respectively, $\mathrm{p}<0.001)$ as compared with healthy subjects $(3.5 \mathrm{pg} / \mathrm{ml})$. And, just like in the previous study [55], there were no significant differences in 8-isoprostane EBC concentrations between the groups of asthmatic children.

Currently known methods for determination of isoprostanes are: ELISA test, liquid chromatography-mass spectrometry and gas chromatography-mass spectrometry.

A large part of the researchers use GC-MS, precisely stable isotope dilution gas chromatography negative ion chemical ionization mass spectrometry, despite the fact that GC-MS methods are quite expensive and time consuming. They are also characterized by the highest sensitivity and specificity.

Isoprostanes are becoming more widely used markers of oxidative stress. Morrow et al. [57] suggest, however, that several potential problems exist. The first one is that artifactual generation of $\mathrm{F}_{2}$-IsoPs may occur in biological specimens (especially plasma) if they are improperly handled. The second one is that, just with cyclooxygenase-derived prostaglandins, the majority of urinary $\mathrm{F}_{2}$-IsoPs may derive from local production in the kidney and may not be the reflection of total body oxidative stress status [58]. That is why Morrow et al. [57] suggest that measuring urinary metabolite of IsoPs is likely to be a more accurate index of systemic oxidant stress status. The major urinary metabolite of 15- $\mathrm{F}_{2 \mathrm{t}}$-IsoP in humans, 2,3-dinor-5,6-dihydro-15$\mathrm{F}_{2 \mathrm{t}}$-IsoP, has been already identified and the method of its determination has been developed [57].

Dorjgochoo et al. [59] investigated whether urinary concentration of $\mathrm{F}_{2}$-IsoP and 2,3-dinor-5,6-dihydro$15-\mathrm{F}_{2 \mathrm{t}}$-IsoP $\left(15-\mathrm{F}_{2 \mathrm{t}}\right.$-IsoP-M) is dependent on plasma concentrations of antioxidants and antioxidants in food and dietary supplements $(\mathrm{N}=845)$. In result, they found out that in subjects who used multivitamin, urinary concentrations of $\mathrm{F}_{2}$-IsoP and $15-\mathrm{F}_{2 \mathrm{t}}$-IsoP-M were lower. Concentrations of $\mathrm{F}_{2}$-IsoP were lower in ginseng users whereas concentrations of $15-\mathrm{F}_{2 \mathrm{t}}$-IsoP-M were lower in subjects who used vitamin E supplement. Plasma concentrations of antioxidant such as $\beta$-carotenes and lycopene were inversely correlated with urinary concentration of $15-\mathrm{F}_{2 \mathrm{t}}-\mathrm{IsoP}-\mathrm{M}$ whereas concentrations of tocopherols were positively associated with $\mathrm{F}_{2}$-IsoP. 
However, as the literature on metabolites of isoprostanes is still limited, it is unclear whether $15-\mathrm{F}_{2 \mathrm{t}}-\mathrm{IsoP}-\mathrm{M}$ is actually a more sensitive biomarker of oxidative stress than $\mathrm{F}_{2}$-IsoP.

\section{CONCLUSIONS}

It is believed that oxidant stress plays an important role in the pathophysiology of numerous human diseases. That is why it is very important to develop methods that could accurately assess oxidative injury in vivo.

Allantoin is a promising biomarker of oxidative stress. There are many researches showing that e.g., in smoking subjects, cancer patients, rheumatoid arthritis patients and diabetes mellitus patients, its concentration was significantly higher than in control groups. The big advantage of allantoin as a biomarker is that it is easy to eliminate the influence of cigarette smoking on its concentration. Because, admittedly, allantoin levels in plasma are higher in subjects who had recently smoked as compared to non-smoking people, after a night abstinence there was no difference in the concentrations of allantoin between smokers and nonsmokers [20].

Most studies concerning the determination of allantoin are based on its determination in plasma. Urine is an easily accessible, non-invasive matrix. That is why there is a need to develop a sensitive and specific method to measure allantoin concentration in urine. It is also important to obtain information on interday and intraday variations of allantoin and to investigate differences in concentration of allantoin between women and men.

The discovery of isoprostanes has made it possible to assess the role of ROS in pathogenesis of various human diseases.

Higher levels of isoprostanes were found in urine of smokers, diabetics and obese subjects. It is suggested that measurement of isoprostanes in cerebro-spinal fluid may be useful in early detection of AD [52]. Measurement of isoprostane levels in exhaled breath condensate provides opportunity to assess the oxidative stress associated with the respiratory system [53].

Quantitative analysis of isoprostanes in biological samples offer new possibilities in studies on optimization of the composition of the diet and food supplementation.

There is a need for further research on isoprostanes and the need to increase knowledge of their metabolites which have been suggested to be more accurate index of systemic oxidant stress status [57].
Allantoin, isoprostanes and metabolites of isoprostanes are a valuable future analytical tool to explore the role of oxidant stress in pathophysiology of human diseases and may be useful for the rational selection of antioxidant doses in diseases where oxidative stress is involved.

The development of methods of processing the samples and analytical techniques will make measurement of these markers even simpler. Thus, diagnostic and medical treatment may become easier.

\section{REFERENCES}

1. Prakash R, Singapalli T, Gokulnath. Review of oxidative stress in relevance to uremia. Clin Queries Nephrol. 2012; 1:215-21, http://dx.doi.org/10.1016/j.cqn.2012.06.002.

2. Small DM, Coombes JS, Bennett N, Johnson DW, Gobe GC. Oxidative stress, antioxidant therapies and chronic kidney disease. Nephrology. 2012;17:311-21, http://dx.doi.org/10.1111/j.1440-1797.2012.01572.x.

3. Yoshikawa T, Naito Y. What is oxidative stress? Jpn Med Assoc J. 2002;45(7):271-6.

4. Nikam S, Nikam P, Ahaley S, Sontakke A. Oxidative stress in Parkinson's disease. Indian J Clin Biochem. 2009;24: 98-101, http://dx.doi.org/10.1007/s12291-009-0017-y.

5. Zhou C, Huang Y, Przedborski S. Oxidative stress in Parkinson's disease: A mechanism of pathogenic and therapeutic signifi-cance. Ann N Y Acad Sci. 2008;1147:93-104, http://dx.doi.org/10.1196/annals.1427.023.

6. Handelman GJ. Evaluation of oxidant stress in dialysis patients. Blood Purif. 2000;18:343-9, http://dx.doi. org/10.1159/000014460.

7. Sies H. Oxidants and antioxidants. Exp Physiol. 1997;82: 291-5, http://dx.doi.org/10.1113/expphysiol.1997.sp004024.

8. Locatelli F, Canaud B, Eckardt K-U, Stenvinkel P, Wanner $\mathrm{C}$, Zoccali C. Oxidative stress in end-stage renal disease: An emerging threat to patient outcome. Nephrol Dial Transplant. 2003;18:1272-80, http://dx.doi.org/10.1093/ ndt/gfg074.

9. Kand'ár R, Žáková P, Mužáková V. Monitoring of antioxidant properties of uric acid in humans for a consideration measuring of levels of allantoin in plasma by liquid chromatography. Clin Chim Acta. 2006;365:249-56, http://dx.doi.org/10.1016/j.cca.2005.09.002.

10. Berthemy A, Newton J, Wu D, Buhrman D. Quantitative determination of an extremely polar compound allantoin in human urine by LC-MS/MS based on the separation on a polymeric amino column. J Pharm Biomed Anal. 1999;19:429-34, http://dx.doi.org/10.1016/S07317085(98)00200-3. 
11. Kim KM, Henderson GN, Frye RF, Galloway CD, Brown NJ, Segal MS, et al. Simultaneous determination of uric acid metabolites allantoin, 6-aminouracil, and triuret in human urine using liquid chromatography-mass spectrometry. J Chromatogr B. 2009;877:65-70, http:// dx.doi.org/10.1016/j.jchromb.2008.11.029.

12. Tolun AA, Zhang H, Il'yasova D, Sztaray J, Young SP, Millington DS. Allantoin in human urine quantified by UPLC-MS/MS. Anal Biochem. 2010;402(2):191-3, http:// dx.doi.org/10.1016/j.ab.2010.03.033.

13. Il'yasova D, Spasojevic I, Wang F, Tolun A, Base K, Young S, et al. Urinary biomarkers of oxidative status in a clinical model of oxidative assault. Cancer Epidemiol Biomarkers Prev. 2010;19(6):1506-10, http://dx.doi. org/10.1158/1055-9965.EPI-10-0211.

14. Tolun AA, Scarbrough PM, Zhang H, McKillop JA, Wang F, Kishnani PS, et al. Systemic oxidative stress, as measured by urinary allantoin and F2-isoprostanes, is not increased in Down syndrome. Ann Epidemiol. 2012;22: 892-4, http://dx.doi.org/10.1016/j.annepidem.2012.09.005.

15. Wu X, Lee Ch, Muzny D, Caskey T. Urate oxidase: Primary structure and evolutionary implications. Proc Natl Acad Sci U S A. 1989;86:9412-6, http://dx.doi.org/10.1073/ pnas.86.23.9412.

16. Grootveld M, Halliwell B. Measurement of allantoin and uric acid in human body fluids. A potential index of freeradical reactions in vivo? Biochem J. 1987;243:803-8.

17. Ames BN, Cathacart R, Schwiers E, Hochstein P. Uric acid provides an antioxidant defense in humans against oxidant- and radical-cause aging and cancer: A hypothesis. Proc Natl Acad Sci U S A. 1981;78(11):6858-62, http:// dx.doi.org/10.1073/pnas.78.11.6858.

18. Moison RMW, de Beaufort AJ, Haasnoot AA, Dubbleman TM, van Zoern-Grobben D, Berger HM. Uric acid and ascorbic acid redox ratios in plasma and tracheal aspirate of preterm babies with acute and chronic lung disease. Free Radic Biol Med. 1997;23(2):226-34, http://dx.doi. org/10.1016/S0891-5849(97)00033-6.

19. Benzie IF, Chung W, Tomlinson B. Simultaneous measurement of allantoin and urate in plasma: Analytical evaluation and potential clinical application in oxidant: Antioxidant balance studies. Clin Chem. 1999;45(6):901-4.

20. Seet RC, Lee Ch-YJ, Loke WM, Huang SH, Huang H, Looi WF, et al. Biomarkers of oxidative damage in cigarette smokers: Which biomarkers might reflect acute versus chronic oxidative stress? Free Radic Biol Med. 2011;50:1787-93, http://dx.doi.org/10.1016/j.freeradbiomed.2011.03.019.

21. Chung W-Y, Benzie IF. Plasma allantoin measurement by isocratic liquid chromatography with tandem mass spectrometry: Method evaluation and application in oxidative stress biomonitoring. Clin Chim Acta. 2013;424: 237-44, http://dx.doi.org/10.1016/j.cca.2013.06.015.

22. Il'yasova D, Kennedy K, Spasojevic I, Wang F, Tolun AA, Base $\mathrm{K}$, et al. Individual responses to chemotherapy-induced oxidative stress. Breast Cancer Res Treat. 2011; 125(2):583-9, http://dx.doi.org/10.1007/s10549-010-1158-7.

23. Gus'kov EP, Prokof'ev VN, Kletskii ME, Kornienko IV, Gapurenko OA, Olekhnovich LP, et al. Allantoin as a Vitamin. Dokl Biochem Biophys. 2004;398:320-4, http://dx.doi.org/10.1023/B:DOBI.0000046649.11374.8d.

24. Yardim-Akaydim S, Sepici A, Özkan Y, Torun M, Şimşek B, Sepici V. Oxidation of uric acid in rheumatoid arthritis: Is allantoin a marker of oxidative stress? Free Radic Res. 2004;38(6):623-8, http://dx.doi.org/10.1080/10 715760410001694044

25. Turner R, Stamp LK, Kettle AJ. Detection of allantoin in clinical samples using hydrophilic liquid chromatography with stable isotope dilution negative ion tandem mass spectrometry. J Chromatogr B. 2012;891-892:85-9, http://dx.doi.org/10.1016/j.jchromb.2012.02.009.

26. Hellsten Y, Tullson PC, Richter EA, Bangsbo J. Oxidation of urate in human skeletal muscle during exercise. Free Radic Biol Med. 1997;22(1/2):169-74, http://dx.doi. org/10.1016/S0891-5849(96)00286-9.

27. Kattygnarath D, Mounier N, Madelaine-Chambrin I, Gourmel B, Le Bricon T, Gisselbrecht C, et al. Quantification of urinary allantoin by capillary zone electrophoresis during recombinant urate oxidase (rasburicase) therapy. Clin Biochem. 2006;39:86-90, http://dx.doi.org/10.1016/ j.clinbiochem.2005.09.013.

28. Muratsubaki H, Enomoto K, Soejima A, Satake K. An enzyme cycling method for measurement of allantoin in human serum. Anal Biochem. 2008;378:65-70, http://dx.doi. org/10.1016/j.ab.2008.04.013.

29. Caussé E, Ribes D, Longlune N, Kamar N, Durand D, Salvayare $\mathrm{R}$, et al. Aminothiols and allantoin in chronic dialysis patients: Effects of hemodialysis sessions. Clin Nephrol. 2010;73(1):51-7, http://dx.doi.org/10.5414/CNP73051.

30. Kurajoh M, Koyama H, Shoji T, Sumida C, Yamamoto A Tsutsumi Z, et al. Relationship between serum allantoin and urate in healthy subjects and effects of benzbromarone in gout patients. Int J Clin Pharmacol Ther. 2012;50(4): 265-71, http://dx.doi.org/10.5414/CP201582.

31. PavittDV, deFonsekaS, Al-KhalafN, Cam JM, Reaveley DA Assay of serum allantoin in humans by gas chromatography-mass spectrometry. Clin Chim Acta. 2002;318(1-2): 63-70, http://dx.doi.org/10.1016/S0009-8981(01)00805-1.

32. Gruber J, Tang SY, Jenner AM, Mudway I, Blomberg A, Behndig $\mathrm{A}$, et al. Allantoin in human plasma, serum 
and nasal-lining fluids as a biomarker of oxidative stress: Avoiding artifacts and establishing real in vivo concentrations. Antioxidants Redox Signaling. 2009;11(8):1767-76, http://dx.doi.org/10.1089/ars.2008.2364.

33. Il'yasova D, Scarbrough P, Spasojevic I. Urinary biomarkers of oxidative status. Clin Chim Acta. 2012;413(19-20): 1446-53, http://dx.doi.org/10.1016/j.cca.2012.06.012.

34. Crankshaw DJ, Rangachari PK. Isoprostanes: More than just mere markers. Mol Cell Biochem. 2003;253:125-30, http://dx.doi.org/10.1023/A:1026052123843.

35. Milne G, Yin H, Jasn D. Human biochemistry of the isoprostane pathway. J Biol Chem. 2008;283:15533-7, http:// dx.doi.org/10.1074/jbc.R700047200.

36. Cracowski JL, Durand T, Bessard G. Isoprostanes as a biomarker of lipid peroxidation in humans: Physiology, pharmacology and clinical implications. Trends Pharmacol Sci 2002;23(8):360-6, http://dx.doi.org/10.1016/S01656147(02)02053-9.

37. Milne GL, Musiek ES, Morrow JD. F2-isoprostanes as markers of oxidative stress in vivo: An overview. Biomarkers. 2005;10:S10-S23, http://dx.doi.org/10.1080/1354750 0500216546.

38. Musiek ES, Brooks JD, Joo M, Brunoldi E, Porta A, Zanoni G, et al. Electrophilic cyclopentanoneneuroprostanes are anti-inflammatory mediators formed from the peroxidation of the $\omega-3$ polyunsaturated fatty docosahexaenoic acid. J Biol Chem. 2008;183(29):19927-35, http://dx.doi. org/10.1074/jbc.M803625200.

39. Song WL, Paschos G, Fries S, Reilly M, Yu Y, Rokach J, et al. Novel eicosapentaenoic acid-derived F3-isoprostanes as bio-markers of lipid peroxidation. J Biol Chem. 2009;284 (35):23636-43, http://dx.doi.org/10.1074/jbc.M109.024075.

40. Roberts LJ, Morrow JD. Measurement of F2-isoproastanes as index of oxidative stress in vitro. Free Radic Biol Med. 2000;28:505-13, http://dx.doi.org/10.1016/S0891-58 49(99)00264-6.

41. Praticò D, Lawson JA, Rokach J, FitzGerald GA. The isoprostanes in biology and medicine. Trends Endocrinol Metab. 2001;12(6):243-47, http://dx.doi.org/10.1016/S10432760(01)00411-8.

42. Morrow JD, Frei B, Longmire AW, Gaziano M, Lynch SM, Shyr $\mathrm{Y}$, et al. Increase in circulating products of lipid peroxidation (F2-isoprostanes) in smokers. N Engl J Med. 1995;332:1198-203, http://dx.doi.org/10.1056/NE JM199505043321804.

43. Gopaul NK, Änggård EE, Mallet AI, Betteridge DJ, Wolff SP, Nouroo-Zadeh J. Plasma 8-epi-PGF2 $\alpha$ levels are elevated in individuals with non-insulin dependent diabetes mellitus. FEBS Lett. 1995;368:225-9, http://dx.doi. org/10.1016/0014-5793(95)00649-T.
44. Keaney JF Jr, Larson Jr MG, Vasan RS, Wilson PWF, Lipinska I, Corey D, et al. Obesity and systemic oxidative stress: Clinical correlates of oxidative stress in the Framingham study. Arterioscler Thromb Vac Biol. 2003;23:434-9, http://dx.doi.org/10.1161/01.ATV.0000058402.34138.11.

45. Reilly MP, Praticò D, Delanty N, DiMinno G, Tremoli E, Rader D, et al. Increased formation of distinct F2 isoprostanes in hypercholesterolemia. Circulation. 1998;98: 2822-8, http://dx.doi.org/10.1161/01.CIR.98.25.2822.

46. Obata T, Tomaru K, Nagakura T, Izumi Y, Kawamoto T. Smoking and oxidant stress: Assay of isoprostane in human urine by gas chromatography-mass spectrometry. J Chromatogr B. 2000;746:11-5, http://dx.doi.org/10.1016/ S0378-4347(00)00182-1.

47. Davì G, Guagnano MT, Ciabattoni G, Basili S, Falco A, Marinopiccoli $\mathrm{M}$, et al. Platelet activation in obese women. Role of inflammation and oxidant stress. JAMA. 2008;288(16):2008-14, http://dx.doi.org/10.1001/ jama.288.16.2008.

48. Davì G, Ciabattoni G, Consoli $\mathrm{A}$, Mezzetti $\mathrm{A}$, Falco $\mathrm{A}$, Santarone S, et al. In vivo formation of 8-iso-prostaglandin F2 $\alpha$ and platelet activation in diabetes mellitus: Effect of improved metabolic control and vitamin E supplementation. Circulation. 1999;99:224-29, http://dx.doi. org/10.1161/01.CIR.99.2.224.

49. Davì G, Chiarelli F, Santilli F, Pomilio M, Vigneri S, Falco A, et al. Enhanced lipid peroxidation and platelet activation in the early phase of type 1 diabetes mellitus: Role of interleukin- 6 and disease duration. Circulation. 2003;107:3199-203, http://dx.doi.org/10.1161/01.CIR. 0000074205.17807.D0.

50. Markesbery WR, Carney JM. Oxidative alterations in Alzheimer's disease. Brain Pathol. 1999;9:133-46, http:// dx.doi.org/10.1111/j.1750-3639.1999.tb00215.x.

51. Praticò D, Iuliano L, Amerio G, Tang LX, Rokach J, Sabatino G, et al. Down's syndrome is associated with increased 8,12-iso-iPF2 $\alpha$-VI levels: Evidence for enhanced lipid peroxidation in vivo. Ann Neurol. 2000;48:795-89, http://dx.doi.org/10.1002/1531-8249(200011)48:5<795:: AID-ANA15>3.0.CO;2-\#.

52. Praticò D, Clark CM, Lee VMY, Trojanowski JQ, Rokach J, FitzGerald GA. Increased 8,12-iso-iPF2 $\alpha$-VI in Alzheimer's disease: Correlation of noninvasive index of lipid peroxidation with disease severity. Ann Neurol. 2000;48:809-12, http://dx.doi.org/10.1002/15318249(200011)48:5<809::AID-ANA19>3.0.CO;2-9.

53. Balanzá SC, Aragones AM, Mir JCC, Ramírez JB, Ivánez R, Soriano AN, et al. Leukotriene B4 and 8-isoprostane in exhaled breath condensate of children with episodic and persistent asthma. J Invest Clin Immunol. 2010;20(3):237-43. 
54. Kharitonov SA, Barnes PJ. Exhales markers of pulmonary disease. Am J Respir Crit Care Med. 2001;63:1693-722, http://dx.doi.org/10.1164/ajrccm.163.7.2009041.

55. Baraldi E, Ghiro L, Piovan V, Carro S, Ciabattoni G, Barnes PJ, et al. Increased exhaled 8-isoprostane in childchood asthma. Chest. 2003;124:25-31.

56. Zanconato S, Carro S, Corradi M, Alinovi R, Pasquale MF, Baraldi E. Leukotriene and 8-isoprostane in exhaled breath condensate of children with stable and unstable asthma. J Allergy Clin Immunol. 2004;113:257-63, http:// dx.doi.org/10.1016/j.jaci.2003.10.046.

57. Morow JD, Zackert WE, Yang JP, Kurhts EH, Callewaert D, Dworski R, et al. Quantification of the major urinary metabolite of 15-F2t-Isoprostane (8-iso-PGF2 $\alpha$ ) by a stable isotope dilution mass spectrometric assay. Anal Biochem. 1999;269:326-31, http://dx.doi.org/10. 1006/abio.1999.4008.

58. Morrow JD, Roberts LJ. The isoprostanes: unique bioactive products of lipid peroxidation. Prog Lipid Res. 1997;36(1):1-21, http://dx.doi.org/10.1016/S0163-7827 (97)00001-5.

59. Dorjgochoo T, Gao YT, Chow WH, Shu X, Yang G, Cai Q et al. Major metabolite of F2-isoprostane in urine may be a more sensitive biomarker of oxidative stress than isoprostane itself. Am J Clin Nutr. 2012;96:405-14, http:// dx.doi.org/10.3945/ajcn.112.034918.

This work is available in Open Access model and licensed under a Creative Commons Attribution-NonCommercial 3.0 Poland License / Ten utwór jest dostępny w modelu open access na licencji Creative Commons Uznanie autorstwa - Użycie niekomercyjne 3.0 Polska - http://creativecommons.org/ licenses/by-nc/3.0/pl/deed.en. 